\title{
Improved Safety for Automotive Lithium Batteries: An Innovative Approach to include an Emergency Cooling Element
}

\author{
Peter Kritzer ${ }^{*}$, Harry Döring2 ${ }^{2}$ Brita Emermacher² \\ ${ }^{1}$ Advanced Product Engineering, Freudenberg Sealing Technologies GmbH \& Co. KG, Weinheim, Germany \\ ${ }^{2}$ Electrochemical Energy Technologies, Zentrum für Sonnenergie und Wasserstoff-Forschung \\ Baden-Württemberg, Ulm, Germany \\ Email: ${ }^{*}$ peter.kritzer@fst.com
}

Received 26 February 2014; revised 26 March 2014; accepted 3 April 2014

Copyright (C) 2014 by authors and Scientific Research Publishing Inc.

This work is licensed under the Creative Commons Attribution International License (CC BY).

http://creativecommons.org/licenses/by/4.0/

(c) (i) Open Access

\section{Abstract}

This paper describes a concept for an independent and redundant safety concept for Lithium batteries in Electric and Hybrid Electric Vehicles. This concept includes an emergency cooling system based on pressurized carbon dioxide $\left(\mathrm{CO}_{2}\right)$. Since carbon dioxide $\left(\mathrm{CO}_{2}\right)$ is a possible medium of future mobile air conditioning (MAC) systems, the MAC system can be utilized for the one-time emergency cooling described in this paper. In the first part of the paper, some major safety aspects of automotive Li batteries are highlighted. In the second section, the paper describes a technical approach, how these batteries can be made safer. Pressurized $\mathrm{CO}_{2}$, which is a promising candidate for cooling liquids used in future mobile air conditioning (MAC) systems, is used to effectively cool down an overheating or up-heating battery in a critical state. The safety system thereby is not based on an electrical effect, but on a direct and fast-reacting thermal conduction, avoiding a thermal runaway of individual cells. The application of the proposed system is to act preventively just before the thermal runaway gets uncontrollable. In this case, the limited amount of $\mathrm{CO}_{2}$, which is available in the MAC system, fulfils the emergency cooling requirements. The combination of standard car components for the concept leads to an only moderate increase of the total weight and the additional system costs. Therefore, the described system might be of interest for car, battery and air conditioning system producers. This paper explains that the synergetic combination of $\mathrm{CO}_{2}$-based MAC systems and Li-based batteries is an innovative approach to improve environmental compatibility in future vehicles. The concept is proven experimentally on a lab scale with battery cells and battery packs consisting of four serially connected cells, respectively.

\footnotetext{
${ }^{*}$ Corresponding author.
}

How to cite this paper: Kritzer, P., et al. (2014) Improved Safety for Automotive Lithium Batteries: An Innovative Approach to include an Emergency Cooling Element. Advances in Chemical Engineering and Science, 4, 197-207. 


\section{Keywords}

\section{Lithium Batteries, Safety, Electric Vehicle (EV), Hybrid Electric Vehicle (HEV), Cooling System, Air Conditioning System, Safety, Thermal Runaway}

\section{Introduction}

The present paper highlights technical trends in two different sectors-EV/HEV batteries and mobile air conditioning (MAC) systems. It describes the synergetic combination of both trends.

The idea of this paper is based on the following facts:

- Hybrid Electric Vehicles (HEVs) will be equipped with Lithium-based batteries (Li-Ion, or Li-Polymer, resp.), which will more or less substitute the current Nickel-Metal Hydrid (NiMH) battery systems for performance reasons.

- Plug-in Hybrid Electric Vehicles (PHEVs) and Pure electric vehicles (EVs) will exclusively be equipped with Lithium batteries.

- However, safety over the complete product life cycle still is a major issue for all Li batteries.

- From 2011 on, the European legislative 2006/40/EG bans partly fluorinated saturated substances like 1,1,1,2Tetrafluoroethane (R134a) from mobile air conditioning (MAC) systems [1]. These substances bear a huge global warming potential (GWP) of approximately 1300 (compared to $\mathrm{CO}_{2}$ ), and therefore significantly contribute to the global greenhouse effect, when emitted into the environment (leakage, scrapping). Current substitutes like $\mathrm{CF}_{3} \mathrm{CF}=\mathrm{CH}_{2}$ (1234yf) are currently favoured media, since they can be more or less used in current MAC systems. However, these substances show significant flammability and therefore, they may be a safety risk [2]. An alternative candidate is carbon dioxide $\left(\mathrm{CO}_{2} ; \mathrm{R} 744\right)$ as a cooling agent [3]. The greenhouse potential of $\mathrm{CO}_{2}$ is by more than three orders of magnitude lower compared to the currently used media and approximately four times lower compared that of R1234yf. In comparison to other replacement candidates, $\mathrm{CO}_{2}$ is completely non-flammable. Furthermore, $\mathrm{CO}_{2}$ based cooling cycles possess much higher heating efficiency at low temperatures, which directly influences the electrical driving range of EVs at low temperatures.

- The $\mathrm{CO}_{2}$ cycle in future air conditioning systems is schematically shown in Figure 1. In the high-pressure part, the $\mathrm{CO}_{2}$ pressure typically is rd $14 \mathrm{MPa}$ (140 bar). An additional disadvantage compared to $\mathrm{CO}_{2}$ is their higher GWP. Some characteristics of the currently used and future cooling media for MAC systems are listed in Table 1.

- $\mathrm{CO}_{2}$ possesses a positive Joule-Thomson coefficient. This means that when $\mathrm{CO}_{2}$ is rapidly expanded from the above-mentioned high pressure, e.g. through a suitable valve or a nozzle, it cools down drastically. Therefore, expanding $\mathrm{CO}_{2}$ can be used as an effective cooling agent.

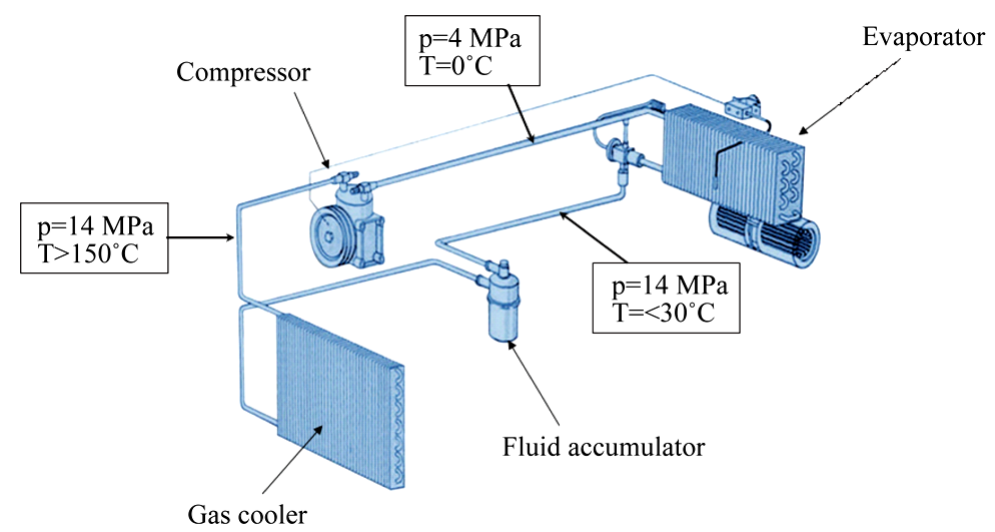

Figure 1. Schematic of a mobile air conditioning (MAC) system based oncarbon dioxide $\left(\mathrm{CO}_{2}\right)$ as a cooling medium [Figure reprinted by kind permission of Freudenberg Sealing Technologies GmbH \& Co. KG, Germany]. 
Table 1. Overview of current and future cooling media for MAC systems.

\begin{tabular}{ccccc}
\hline & $\mathrm{R} 134 \mathrm{a}$ & $\mathrm{R} 1234 \mathrm{yf}$ & $\mathrm{R} 1234 \mathrm{yf}+\mathrm{CF}_{3} \mathrm{I}$ & $\mathrm{R} 744$ \\
\hline Chemical formula & $\mathrm{CF}_{3}-\mathrm{CFH}_{2}$ & $\mathrm{CF}_{3} \mathrm{CF}=\mathrm{CH}_{3}$ & $\mathrm{CF}_{3} \mathrm{CF}=\mathrm{CH}_{3} / \mathrm{CF}_{3} \mathrm{I}$ & $\mathrm{CO}_{2}$ \\
Toxicity & no & no & yes & no \\
Flammability & no & yes & no & no \\
GWP & 1300 & $3-4$ & $3-4$ & 1 \\
Reactivity with Lithium & yes & yes & yes & no \\
Usable in current MAC systems & Currently standard & yes & yes & No; re-design necessary \\
\hline
\end{tabular}

*GWP = Global Warming Potential; normalized on $\mathrm{CO}_{2}$.

\section{The Safety Aspect of Lithium Batteries}

The safety aspect of Li-based batteries is well known [4]-[9]. Table 2 gives an overview for the typical requirements of Li battery systems used in consumer and automotive applications. For automotive batteries, safety requirements become much more important not only due to the higher energy amounts, but also due to the harsher environments and lifetime requirements. Thus, "safety” is the most important task for traction battery systems in automotive systems.

The present approach gives an additional, redundant tool to effectively and safely shut down a Li-ion battery in a critical, overheated state. This approach is based on an cell-external feature, so the electrochemistry itself is not influenced by this system.

The components/aggregates used for this system are already present in a future car, so the additional safety feature does not need much additional equipment. Consequently, weight increase and additional costs for the car are low to moderate

\section{The Concept of a Redundant and Independent Safety System}

Automotive fire extinguishing equipment based on $\mathrm{CO}_{2}$ as medium is described in patent literature [10]. It is also described to use $\mathrm{CO}_{2}$ coming from a MAC system to extinguish a burning battery [11]. However, all these concepts are not transferable to EV applications, since the amount of $\mathrm{CO}_{2}$ necessary to extinguish a battery-initiated fire exceeds the amount of $\mathrm{CO}_{2}$ in an automotive MAC.

Therefore, the present concept uses the $\mathrm{CO}_{2}$ of the MAC only to cool down the battery prior to any fire and/or explosion [12].

Basic feature of the safety system described in this paper is a pressure tube starting in the high-pressure, $\mathrm{CO}_{2}$ containing part of the MAC system [12]. At this point, $\mathrm{CO}_{2}$ is in its semi-critical state (the pressure is typically $14 \mathrm{MPa}$, which is above the critical pressure of $7.3 \mathrm{MPa}$, but the temperature is just below the critical temperature of $31^{\circ} \mathrm{C}$ ). Through this tube, $\mathrm{CO}_{2}$ can be transported from the MAC circuit system, normally towards the HEV/EV battery. The tubing could be placed together with the electrical cables linking the battery and the electric engine. The system is schematically shown for a HEV in Figure 2.

The tube ends inside the battery housing, close to the cells. Under normal conditions, it is completely filled with semi-critical $\mathrm{CO}_{2}$. At the outlet point, a special expansion valve is placed, which can control the rapidly expanding and cooling medium.

In case of a malfunction of the battery, this valve is opened and the highly-compressed liquid $\mathrm{CO}_{2}$ expands through this nozzle forming gaseous or solid $\mathrm{CO}_{2}$. Thereby, it rapidly cools down due to the positive JouleThomson-Effect coefficient for $\mathrm{CO}_{2}$. This cooling effect can be effectively used to cool down individual cells inside the battery. The refrigeration capacity of $\mathrm{CO}_{2}$ amounts to $645 \mathrm{~kJ} / \mathrm{kg}$ referring to a temperature increase from $-79^{\circ} \mathrm{C}$ to $0^{\circ} \mathrm{C}$.

The gas outlet system itself can be combined intelligently with the battery management system (BMS), or it can possess a redundant sensor (e.g. temperature measurement by additional thermocouples, or a pressure measurement detecting an extraordinary pressure increase in stack pressure). Ideally, it should activate, when cells reach critical values, and before a real "battery accident” occurs.

By using multiple expansion valves and tubes placed in different sections of the battery, a selective cooling of single overheating cells is possible (see Figure 3). This assembly allows the direct release of the cooling me- 
Table 2. Typical parameters for Li batteries used in consumer and automotive.

\begin{tabular}{ccc}
\hline & Batteries in Consumer Applications & Batteries in Automotive Applications \\
\hline Mass Battery system & $<0.1 \mathrm{~kg}$ & $>100 \mathrm{~kg}$ \\
Cell capacity & $1 \mathrm{Ah}$ & $>20 \mathrm{Ah}$ \\
System Energy & $0.002 \ldots 0.02 \mathrm{kWh}$ & $1 \mathrm{kWh}(\mathrm{HEV})>15 \mathrm{kWh}(\mathrm{EV})$ \\
System Voltage & $3.6 \ldots 11 \mathrm{~V}$ & $>100 \mathrm{~V}$ \\
Max. Discharging Currents & $<1 \mathrm{~A}$ & $>100 \mathrm{~A}$ \\
Max. Charging Currents & $<1 \mathrm{~A}$ & $-\mathrm{A}$ \\
Operating Temperature & $0 \ldots 40^{\circ} \mathrm{C}$ & $-40 .+85^{\circ} \mathrm{C}$ \\
Further Conditions & Dust; Splash Water & Dirt, Oil, Water, Vibrations \\
Typical Specified Lifetime & 3 years & $>10-15$ years \\
Typical Tolerated Scrap Rate (Cells) & $0.1 \%$ & $\ll 1 \mathrm{ppm}$ \\
\hline
\end{tabular}

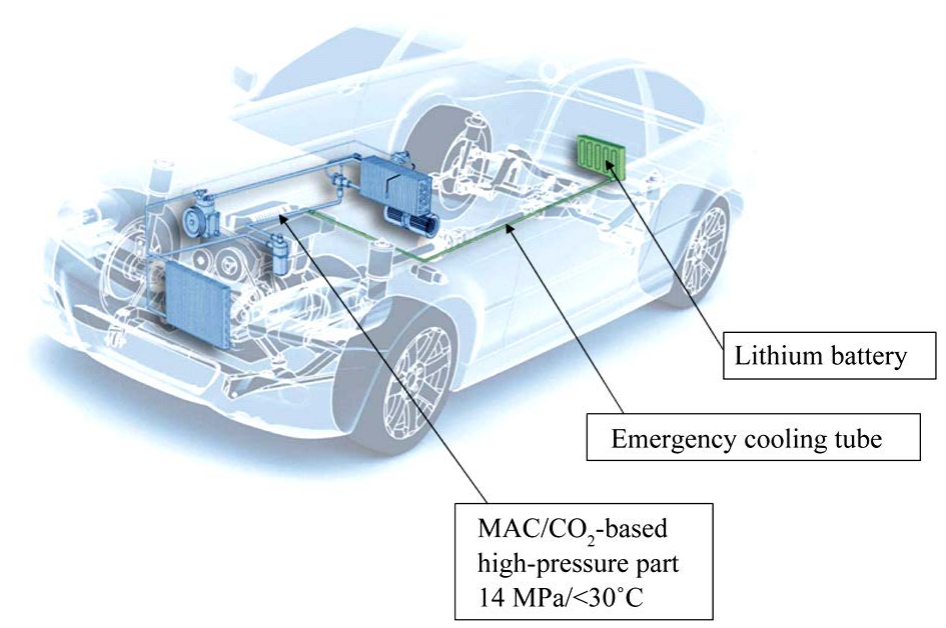

Figure 2. Concept for combining $\mathrm{CO}_{2}$-based mobile air conditioning (MAC) systems and HEV/EV Lithium battery. In case of emergency (especially overheating of the battery), the $\mathrm{CO}_{2}$ can be used to rapidly and effectively cool down the battery medium [figure reprinted by kind permission of Freudenberg Sealing Technologies GmbH \& Co. KG, Germany].

dium precisely into these areas, where the overheating is detected, which assures an economic and effective use of the cooling medium in case of emergency.

In order to reduce leakage through the elastomeric seals and thus to prolong service times of the MAC, a main valve may be placed in the main tube front of the branching. By using elastomers with low values $\mathrm{CO}_{2}$ penetration [13], the long-term effectiveness of the system can be guaranteed.

A less complicated system can be generated if the pressure tubes are equipped with melting fuses at the cell end. When cell surface temperature exceeds values of approx. $80^{\circ} \mathrm{C}-100^{\circ} \mathrm{C}$, the fuses open immediately and emit the cooling media onto the surface.

\section{Experimental Set up}

The concept has been tested in a lab scale at ZSW, Ulm, Germany. Battery failure was induced by a severe overcharge process. As usually, Li batteries do not have a side reaction employable for overcharge, overcharge processes are leading to a damage of the system and might be happen in a catastrophic event.

Model cell

For the study, a laminated sheet cell (LSB; Kokam, KR) has been used. The nominal capacity of the cell was 


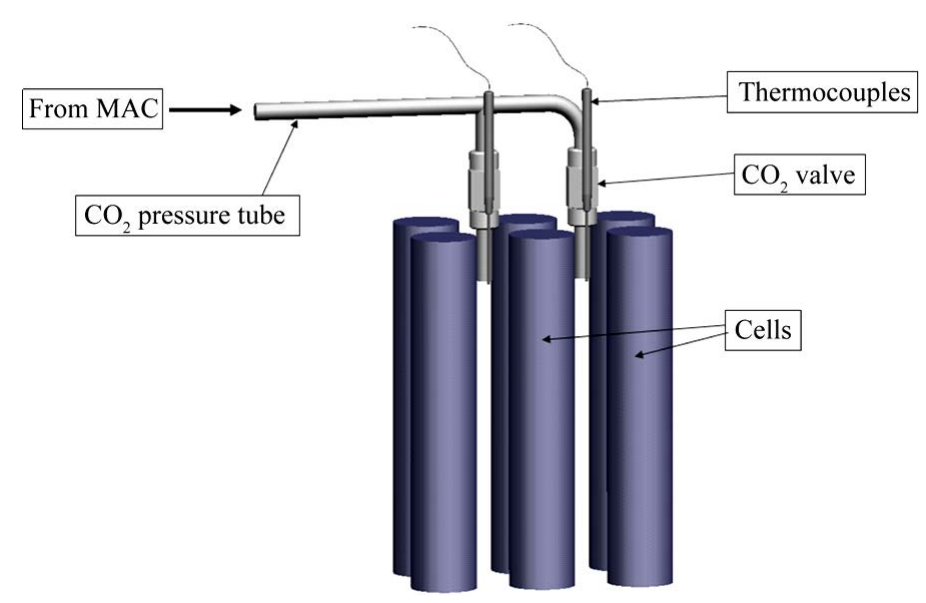

Figure 3. Schematic view of a battery system consisting of round cells equipped with thermocouples and cooling system. Each thermocouple is linked with a $\mathrm{CO}_{2}$ tube and a corresponding outlet valve. This arrangement allows the directed release of the cooling medium into exact these areas, where the overheating is detected. This assures the economic and effective use of the cooling medium in case of emergency [figure reprinted by kind permission of Freudenberg Sealing Technologies $\mathrm{GmbH}$ \& Co. KG, Germany].

4.0 Ah and the nominal voltage $3.7 \mathrm{~V}$.

Tow thermocouples (type K) have been mounted to the front and the backside of the cell.

$\mathrm{CO}_{2}$ dosage.

$\mathrm{CO}_{2}$ came from a pressurized reservoir $\left(\mathrm{p}=5.8 \mathrm{MPa} @ 20^{\circ} \mathrm{C}\right)$ and was filled in a pressure stable tube (volume ca $170 \mathrm{ml}$ ). Than the main reservoir was closed, so that the total amount of the $\mathrm{CO}_{2}$ was limited $(\mathrm{p}=5.8 \mathrm{MPa}$, $170 \mathrm{ml}$ ). The outlet nozzle (diameter $2 \mathrm{~mm}$ ) of the tube was controlled by a magnetic valve. The arrangement of the testing equipment is shown in Figure 4.

\subsection{Cell Overcharge (5C/8.4V/Cell) without Emergency Cooling}

The cell was pre-charged to $85 \%$ SOC and was fastened to a piece of insulation material. Overcharge was at 20 A (corresponding to a charging rate of 5C). The cell inflated, opened and released electrolyte vapour. When a voltage of $8.4 \mathrm{~V}$ was reached (after approx. 8 min of overcharging), charging was terminated (switch off the charger).

At this state (ca. $153 \%$ SOC), temperatures at the cell surfaces were about $90^{\circ} \mathrm{C}$. In the following rd. 8 min, cell surface temperature gradually increased to values of $120^{\circ} \mathrm{C}-170^{\circ} \mathrm{C}$ (self heating). Then, suddenly, the cell ruptured with flying sparks and smoke emission. The cell rupture was most probably due to a melt-down of the separator (thermal runaway occurred) and the cell burned. On the back cell surface temperatures of $485^{\circ} \mathrm{C}$ and on the front surface of $306^{\circ} \mathrm{C}$ were reached. The fire was extinguished.

The course of the experiment is shown in Figure 5 and the destroyed cell in Figure 6.

\subsection{Cell Overcharge (5C/8.4V/Cell) with Emergency Cooling}

The experiment was started in analogy to the previous test. After having reached the charging voltage limitation of $8.4 \mathrm{~V}$, the charging was stopped at a similar point as before. The surface temperature of the cell was around $90^{\circ} \mathrm{C}$. A steady surface temperature rise was observed for further $9 \mathrm{~s}$ after charging stopped. At that point the cell was cooled down by a 20 sec pulse of expanded $\mathrm{CO}_{2}$ (approx. $50 \mathrm{~g}$ ). Front Surface cell temperature immediately dropped down from $93^{\circ} \mathrm{C}$ to $-49^{\circ} \mathrm{C}$. After $\mathrm{CO}_{2}$ pulse stop, cell surface temperature increased again to values of max. $90^{\circ} \mathrm{C}$ (back side) and $\max 78^{\circ} \mathrm{C}$ on the front side, but than temperature cooled down gradually. No rupture occurred.

The course of the experiment is shown in Figure 7; cell open, but not ruptured in Figure 8. 


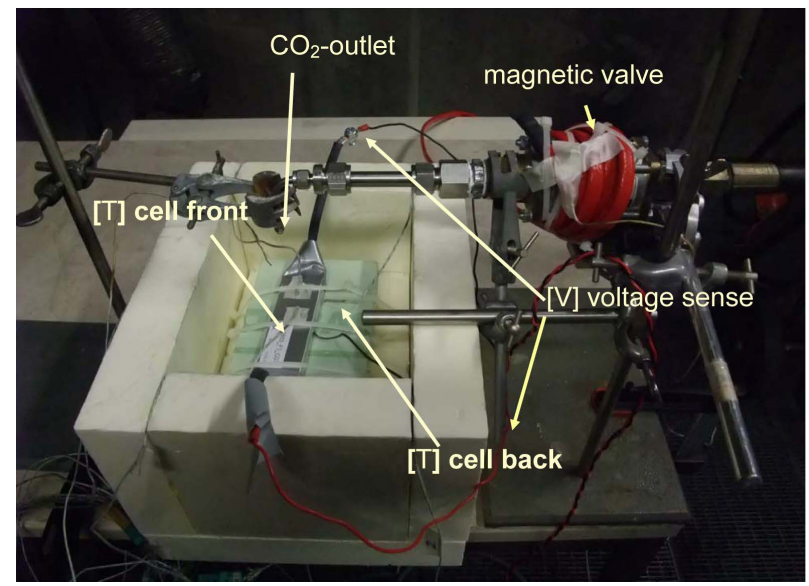

Figure 4. Test set up with LSB cell, temperature sensors and $\mathrm{CO}_{2}$-cooling outlet.

Overcharge single cell with $5 \mathrm{C}=20 \mathrm{~A} / 8.4 \mathrm{~V}$

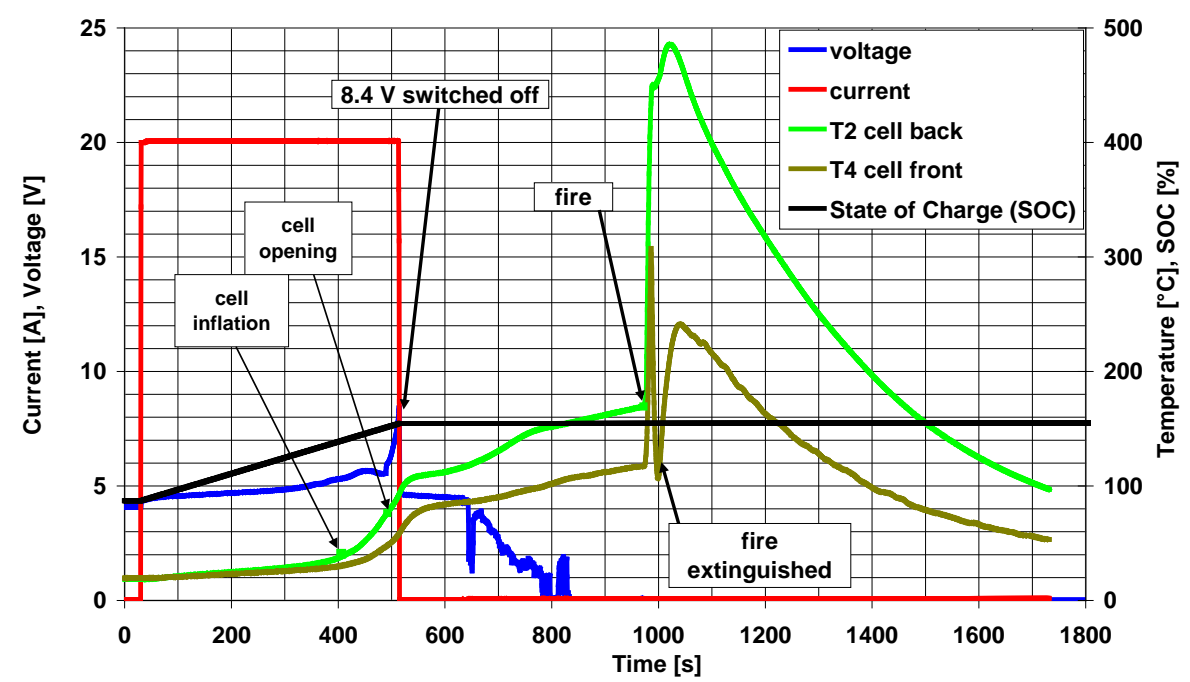

Figure 5. Course of experiment with one cell, without emergency cooling. The internal overheating of the cell finally resulted in a rupture/fire.

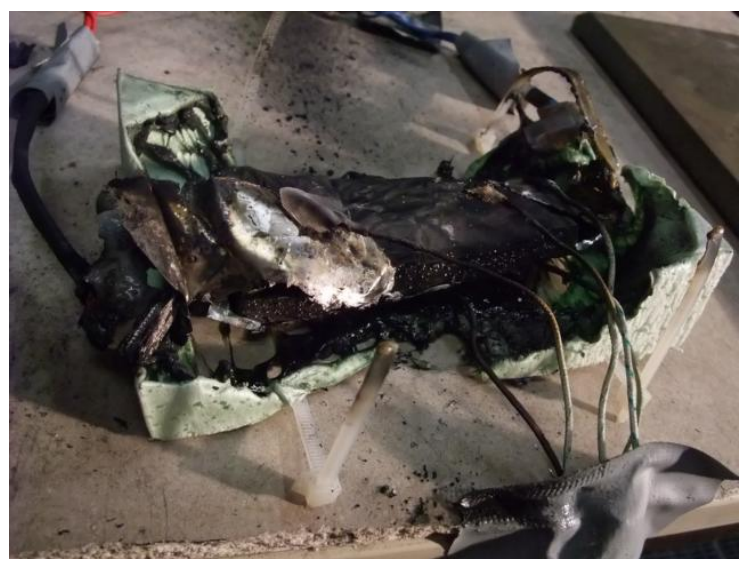

Figure 6. Destroyed overcharge cell after the test, burned and ruptured. 


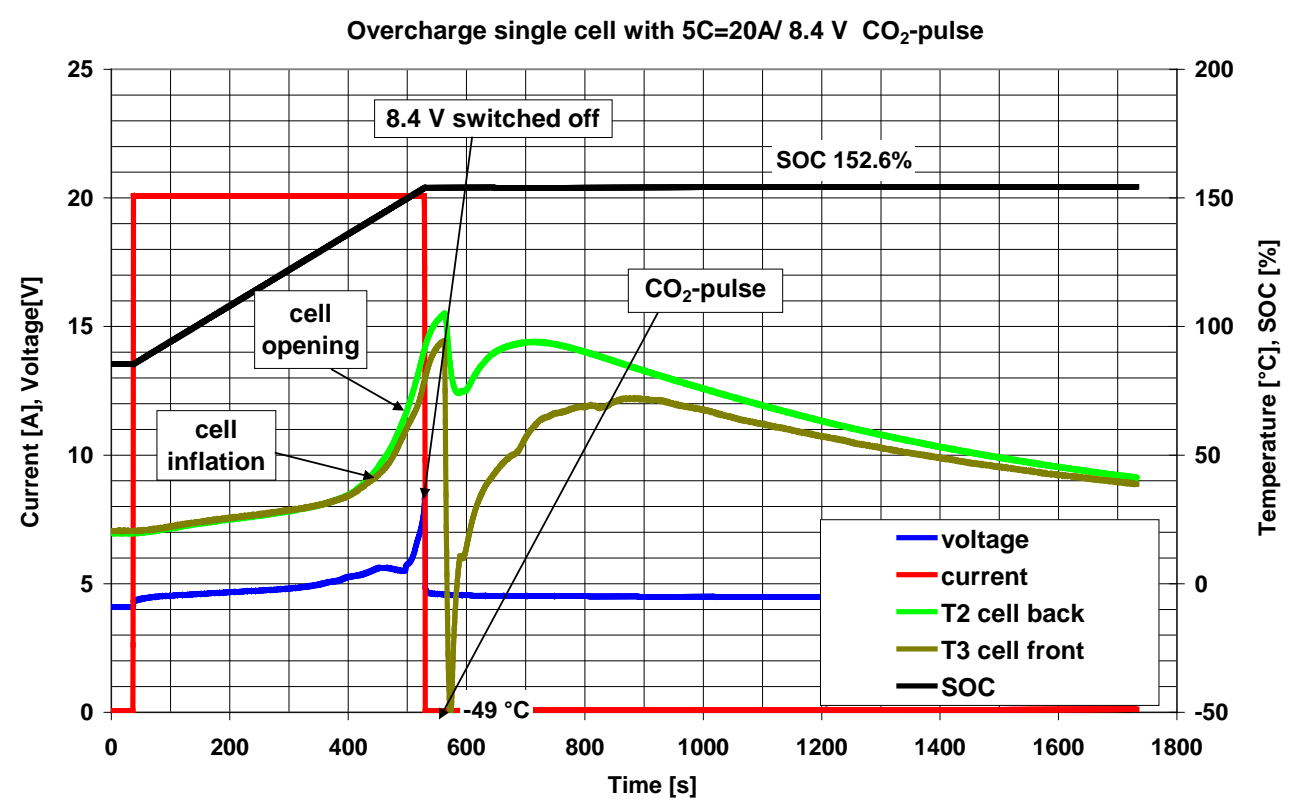

Figure 7. Course of experiment with one cell, with emergency cooling at $t=550 \mathrm{~s}$. No internal overheating of the cell occurred; neither a rupture nor a fire was observed.

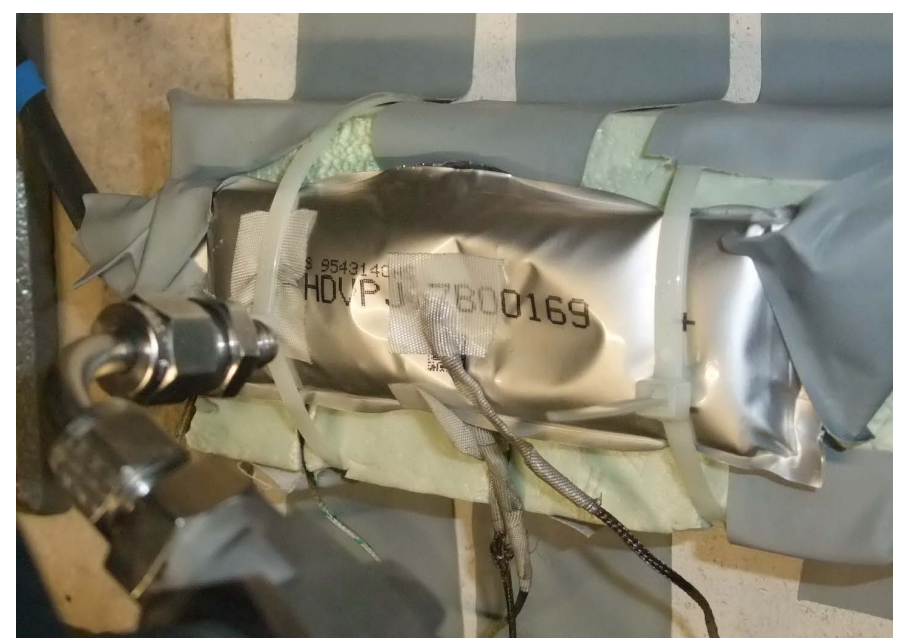

Figure 8. Cell after emergency cooling experiment. Cell inflated and the $\mathrm{CO}_{2}$ pulse resulted in a dented cell. No cell rupture occurred.

When the cell was switched off at the same critical point, in one case, the disaster occurred. However, with a short cooling pulse through expanded $\mathrm{CO}_{2}$, the mode could be switched over and the cell was safe.

\subsection{4-Cell Pack Overcharge (5C) without Emergency Cooling}

A battery pack of 4 cells (connected in series; side-by side-arrangement) was used for the following two experiments. The intention of the experiment is to analyse, whether a failure in a single cell is propagated to its neighbours. In this case, a failing cell would cause a catastrophic failure of the whole battery. If so, it would be important to detect the failure of this single cell as early as possible and to transfer the cell into a safe status; realising this on time, the whole battery could be protected by a minimum of action.

For this test, a particular cell (9) (Figure 9) has a significant higher SOC compared to the other 3 cells (7, 8, 10). The state of charge (SOC) of one of the inner cells was $50 \%$ while the other 3 cells had an SOC of $0 \%$. The course of the experiment is shown in Figure 10. The pack was (over) charged with 20 A (corresponding to a 


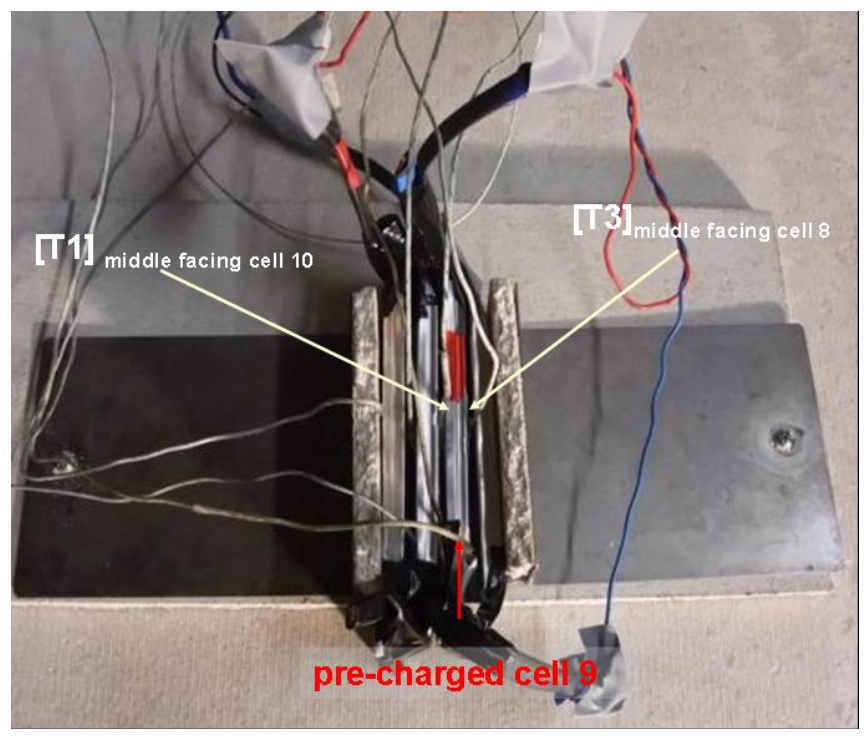

Figure 9. Test set up with pack consisting of 4 serial LSB cells,

SOC of cell 9 was $50 \%$ and for the remaining three cells $0 \%$.

Setup for Module 4 (4 cells in series): $\mathrm{CN}=4 \mathrm{Ah}$

start: cells 5,8,10: $0 \%$ SOC, cell 9: $50 \%$ SOC/ charge $20 \mathrm{~A}$

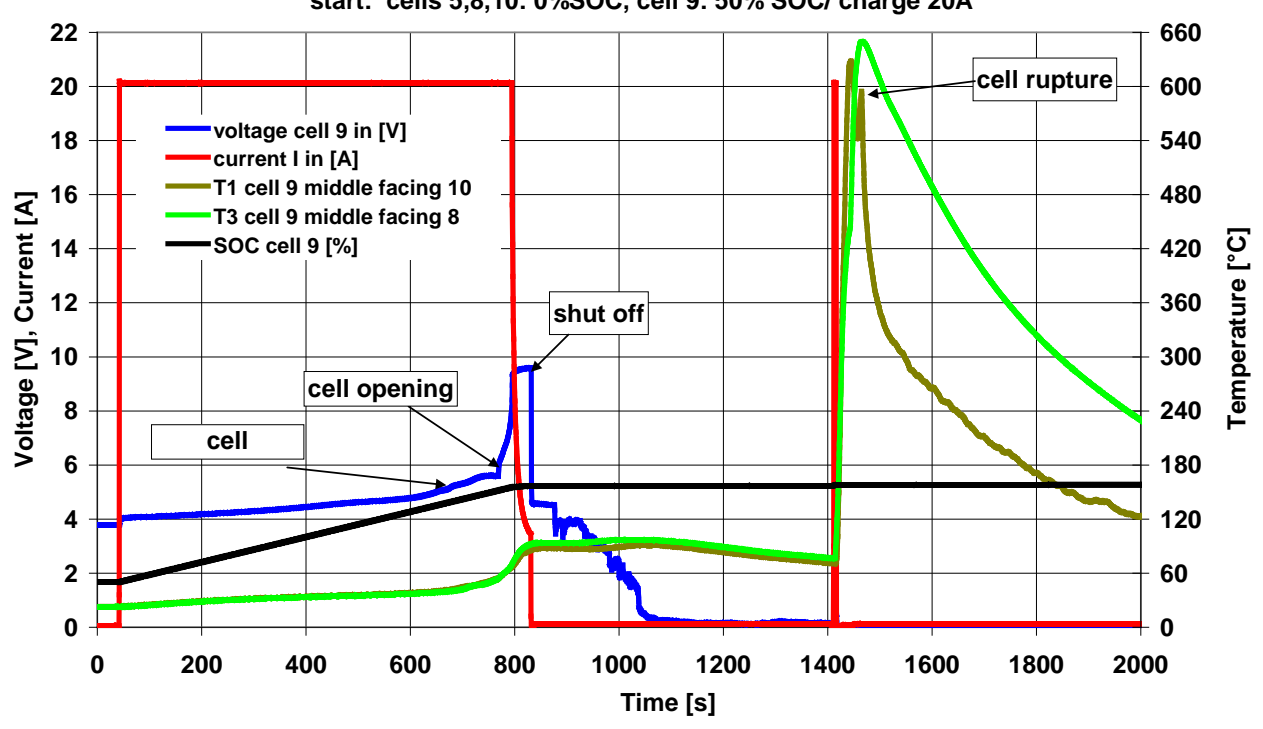

Figure 10. Course of experiment without emergency cooling. cell failing during restart charge resulted in an rupture/fire of the whole pack.

charging rate of 5C). As the cell voltage of the pre-charged cell 9 could not be controlled separately, the overall voltage for the 4 series connected cells was limited to $23 \mathrm{~V}$.

The cell inflated, opened and released electrolyte vapour at a SOC between 140 to $150 \%$. When the overall voltage limit of $23 \mathrm{~V}$ was reached (after 830 seconds), charging was terminated. Cell voltage dropped to $4.5 \mathrm{~V}$ and decreased in the following. Further increase in temperature was observed, however, to a lower extent compared to the single cell behaviour. This might be related to the additional heat transfer to the cell neighbours, which are not overcharged yet. This allows the overcharged cell to steady, and the cell is cooling down slowly, without the expected cell rupture and fire.

However, when switching on the charger again, the cell caught fire immediately and ruptured. The fire was transferred to the neighbouring cells and the whole module was damaged as shown in Figure 11. As anticipated, not only the overcharged cell was damaged, the failure spread to the other cells as well. 


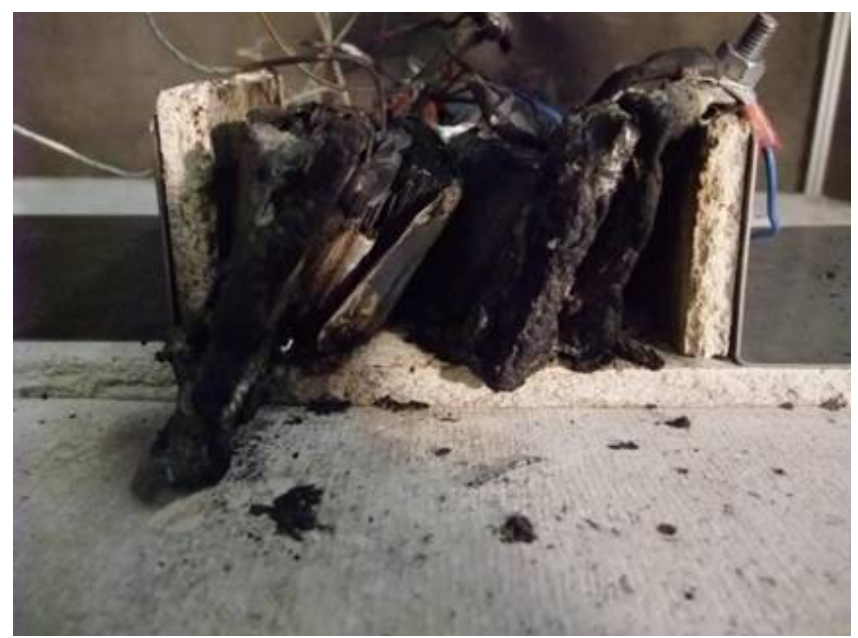

Figure 11. Module of 4 cells after overcharge of a single cell.

\subsection{4-Cell Pack Overcharge (5C) with Emergency Cooling}

The setup corresponds to experiment C. The prepared cell 9 was pre-charged to $90 \%$ SOC, while the other cells were charged to 50\% SOC. The course of the experiment is shown in Figure 12. The pack was (over)charged with $20 \mathrm{~A}$ (corresponding to a charging rate of 5C).

Cell 9 inflated, opened and released electrolyte. When module voltage reached 23V the charging current was stopped. The $\mathrm{CO}_{2}$-pulse was immediately released after the module charging had been stopped. The temperature dropped down by the $\mathrm{CO}_{2}$ pulse and recovered to a level about $20^{\circ} \mathrm{K}$ below the previous temperature. Afterwards, a slow continuous decrease in temperature was observed and the cell voltage kept at around $4.5 \mathrm{~V}$. Neither the cell nor the module was ignited and no cell rupture was observed.

\section{Discussion of the Results}

The above experiments show, that a high power Lithium battery in a critical, overcharged state can effectively be switched down to a safe level by the described emergency cooling concept.

Parallel experiments without the emergency cooling resulted in rupture and fire of the cells.

A "scale-up" of the concept to a small pack consisting of four serial cells showed similar results.

In both cases, the amount of the emergency cooling medium $\mathrm{CO}_{2}$ can be adjusted to a low level, so the amount of cooling medium coming from a MAC system (rd. $500 \mathrm{~g}$ ) is sufficient to economically cool down cells in an automotive Li battery from a critical to a safe. This amount might not be high enough to extinguish the battery once it is burning.

For the tests, a very high voltage limit was used for triggering the emergency cooling. However, the trigger for initiating the emergency cooling might be as well the temperature measured with a thermocouple at the cell surface or any other signals (e.g. stack pressure). In later automotive applications, the sensor signal might be connected to the battery management system, and the occurrence of different signals and their combination might be used as a trigger signal, avoiding faulty activation. Completely stand-alone arrangements might be possible as well. Such can be fusible cut-outs at the ends of the tube outlets, melting and opening when temperature exceeds some $90^{\circ} \mathrm{C}-100^{\circ} \mathrm{C}$ and thus release the pressurized $\mathrm{CO}_{2}$. (Figure 13)

\section{Conclusions}

This paper describes a concept increasing safety of Hybrid Electric Vehicles (HEVs) and Electric Vehicles (EVs) equipped with Lithium-based batteries. Further battery sealing-relevant products are described elsewhere [14].

Currently, automotive Li batteries are equipped with a State of Charge (SoC) sensor on cell basis. Thus, an automotive battery system requires some 100 - 200 individual wires, which are contacted to the power electronic system.

This raises two questions in this content: 
Overcharge Module 1 (4 cells in series) start: cells $5,8,10: 50 \% \mathrm{SOC}$, cell $9: 90 \% \mathrm{SOC} /$ charge $20 \mathrm{~A}, \mathrm{CO}_{2}$-cooling pulse

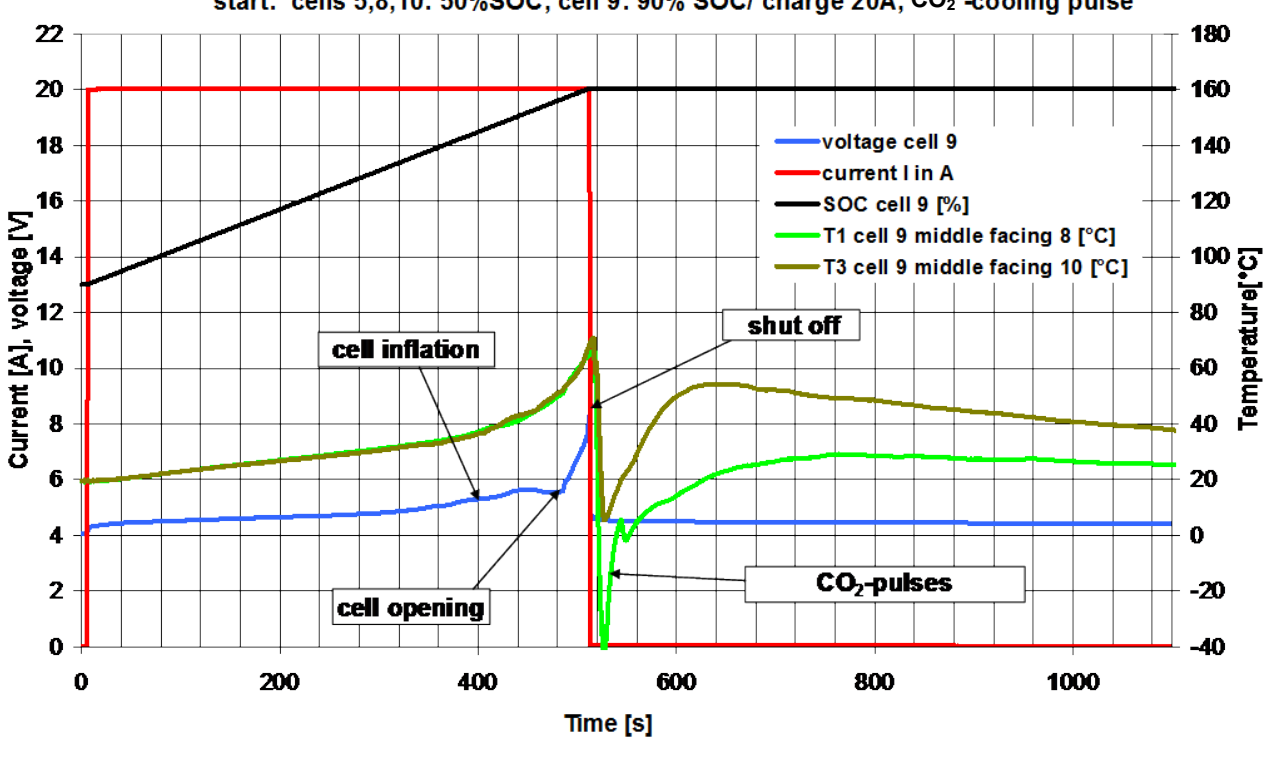

Figure 12. Course of experiment with a battery pack, with emergency cooling no internal overheating of the pack occurred; neither a rupture nor a fire was observed.

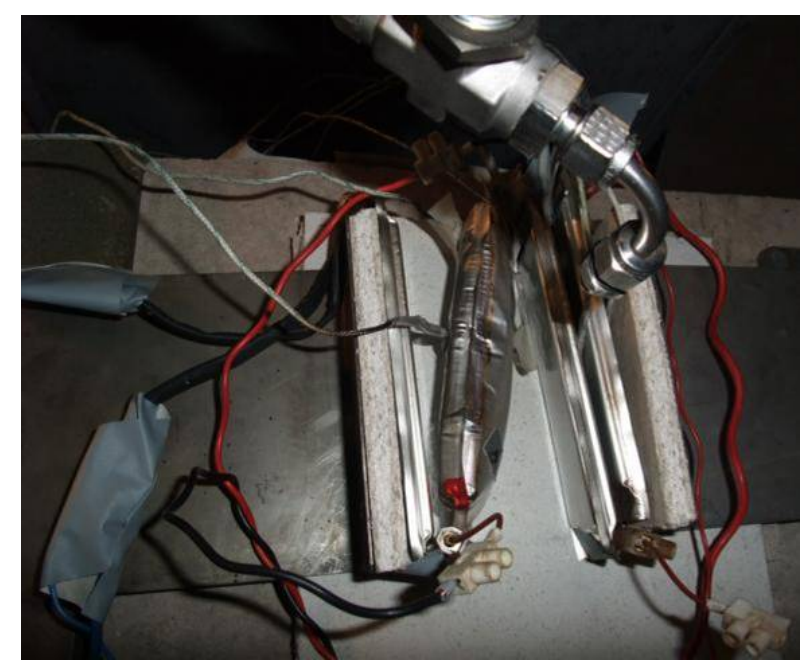

Figure 13. Cell 9 inflated / module with $\mathrm{CO}_{2}$-cooling.

- What happens, if the electrical contact of one of the tiny sensor wires is opened/destroyed? If so, will the driver of an EV immediately be informed in this case?

- Will future battery systems be equipped with a sensor system on cell basis?

If one of the questions is answered with "no", a single cell overcharging with high charging currents cannot be excluded. In such a case, a critical, overheating state as it is simulated in the present article cannot be excluded.

The additional safety described here can help to avoid the final consequences of battery fire/explosion. The safety system consists of a synergetic combination of a $\mathrm{CO}_{2}$-containing mobile air conditioning (MAC) system and the Li-based battery system. In case of cell overheating, the compressed $\mathrm{CO}_{2}$ inside the MAC system can be expanded into the battery leading to a rapid and effective cool-down due to its positive Joule-Thomson coefficient. It must be clearly pointed out that the focus of the concept is to cool down parts of the battery selectively in order to prevent an ignition. The amount of $\mathrm{CO}_{2}$ in a MAC system is by far not sufficient to extinguish an already existing fire. 
The concept has been proven in lab-scale experiments in this paper. It has been shown that a high power Lithium battery in a critical, overcharged state can effectively be switched down to a safe level by the described emergency cooling concept. Parallel experiments without the emergency cooling result in rupture and fire of the cells. A "scale-up" of the concept to a small pack consisting of four serial cells shows similar results.

From the point of view of a car producer, the concept should be attractive, since additional costs and weight of this redundant safety system are moderate. On the other hand, this additional safety effect helps to support the implementation of the energy-efficient $\mathrm{CO}_{2}$-containing MAC systems for automotive applications.

Therefore, the synergetic combination of $\mathrm{CO}_{2}$-based MAC systems and Li-based automotive batteries can be seen as an innovative approach to improve environmental compatibility of future vehicles.

\section{References}

[1] European Parlament Regulation: RICHTLINIE 2006/40/EG des Europäischen Parlaments und des Rates vom 17. Mai 2006 üBer Emissionen aus Klimaanlagen in Kraftfahrzeugen und zur Änderung der Richtlinie 70/156/EWG des Rates; Amtsblatt der Europäischen Union 14.06.2006, L 161/12-L 161/18.

[2] Graz, M. and Wuitz, U. (2008) Flammability Investigation of Different Refrigerants Using an Operating MAC System in a Simulated Front End Collision Situation. www.r744.com

[3] Morgenstern, C. (2008) R744 MAC Status and System Standardisation. VDA Winter Meeting, Saalfelden.

[4] Roth, E.P., Doughty, D.H. and Pile, D.L. (2007) Effects of Separator Breakdown on Abuse Response of 18650 Li-Ion Cells. Journal of Power Sources, 174, 579-583. http://dx.doi.org/10.1016/j.jpowsour.2007.06.163

[5] Doh, C.H., Kim, D.H., Kim, H.S., Shin, H.M., Jeong, Y.D., Moon, S.I., Jin, B.S., Eom, S.W., Kim, H.S., Kim, K.W., Oh, D.H. and Veluchamy, A. (2008) Veluchamy: Thermal and Electrochemical Behaviour of $\mathrm{C} / \mathrm{Li}_{\mathrm{x}} \mathrm{CoO}_{2}$ Cell During Safety Test. Journal of Power Sources, 175, 881-885. http://dx.doi.org/10.1016/j.jpowsour.2007.09.102

[6] Balakrishnan, P.G., Ramesh, R. and Kumar, T.P. (2006) Safety Mechanisms in Lithium-Ion Batteries. Journal of Power Sources, 155, 401-414. http://dx.doi.org/10.1016/j.jpowsour.2005.12.002

[7] Arora, P. and Zhang, Z. (2004) Battery Separators. Chemical Reviews, 104, 4419-4462. http://dx.doi.org/10.1021/cr020738u

[8] Zhang, S.S. (2007) A Review on the Separators of Liquid Electrolyte Li-Ion Batteries. Journal of Power Sources, 164, 351-364. http://dx.doi.org/10.1016/j.jpowsour.2006.10.065

[9] Zhang, S.S. (2006) A Review on Electrolyte Additives for Lithium-Ion Batteries. Journal of Power Sources, 162, 1379-1394. http://dx.doi.org/10.1016/j.jpowsour.2006.07.074

[10] Ostlyngen, T.W. and Thrones, B. (1996) Method and Apparatus for Detection and Prevention of Fire Hazard. International Patent WO 96/16699.

[11] Wertenbach, J. and Albersfelder, G. (1995) Kraftfahrzeug Mit Einer Klimaanlage, European Patent Application EP 0 675013 A1.

[12] Kritzer, P. and Raida, H.J. (2011) Method for Cooling of an Energy Storage Device. European Patent EP 2045852 B1.

[13] Frenzel, U., Weiss, R. and Peterseim, V. (2008) Für saubere Luft-Dichtungsloesungen Mit Geringer $\mathrm{CO}_{2}$-Permeation Fuer R744-Klimaanlagen. Automobilkonstruktion, 1, 42-43.

[14] Kritzer, P., Nahrwold, O., Ewig, T., Schreiner, M. and Reinhardt, H. (2012) Components for Improved Lithium Battery Systems: Pressure Regulation and Fluid Control. Sealing Technology, 2012, 9-12. http://dx.doi.org/10.1016/S1350-4789(12)70017-X 